\title{
Distribution and prevalence of scurf (Monilochaetes infuscans) on sweet potato (Ipomea batatas) in West Java, Indonesia
}

\author{
SITARESMI DEWAYANI ${ }^{1, \vartheta}$, HARIS MAULANA ${ }^{2}$, NOLADHI WICAKSANA ${ }^{2}$, TARKUS SUGANDA ${ }^{2}$, \\ VERGEL CONCIBIDO ${ }^{3}$, AGUNG KARUNIAWAN ${ }^{2,4, \bullet \vee}$ \\ ${ }^{1}$ Office of Food Crops and Horticulture of West Java Province, Indonesia. Jl. Surapati No. 71, Sadang Serang, Coblong, Bandung 40133, West Java, \\ Indonesia. Tel.: +62-22-2503884, `email: sitaresmid@gmail.com \\ ${ }^{2}$ Faculty of Agriculture, Universitas Padjadjaran. Jl. Raya Bandung-Sumedang Km. 21, Jatinangor, Sumedang 45363, West Jawa, Indonesia. \\ Tel.: +62-22-84288842, Fax.: +62-22-84288843, ^v email: agung.karuniawan@unpad.ac.id \\ ${ }^{3}$ Sensient Colors, LLC, 2515 North Jefferson Avenue, St. Louis, Missouri, 63106, United States of America \\ ${ }^{4}$ Bioresources Management, Graduate School, Universitas Padjadjaran. Jl. Dipati Ukur No. 35, Bandung 40133, West Jawa, Indonesia
}

Manuscript received: 30 March 2021. Revision accepted: 26 April 2021.

\begin{abstract}
Dewayani, Maulana H, Wicaksana N, Suganda T, Concibido V, Karuniawan A. 2021. Distribution and prevalence of scurf (Monilochaetes infuscans) on sweet potato (Ipomea batatas) in West Java, Indonesia. Biodiversitas 22: 2876-2883. Scurf (Monilochaetes infuscans) is a common sweet potato (Ipomoea batatas (L.) Lam.) tuber skin discoloration disease, that can cause significant yield loss, especially when tubers are destined for the export market. Despite the economic importance of the disease in West Java, Indonesia, there is a dearth of information on the distribution and severity of scurf disease. To address this gap, a disease survey was carried out across 28 fields in six districts (Bandung, Sumedang, Garut, Kuningan, Cianjur, and Bogor) of West Java from 2016 to 2018. Scurf disease prevalence was recorded by counting the number of infected tubers from 15 plant samples per field. Disease incidence was recorded when at least one infected tuber per plant was observed. Severity of scurf diseases was estimated by measuring the percentage of infected surface area, using AutoCAD map 2019. Results show that scurf was distributed across all locations surveyed. Disease incidence ranged from $1.68 \%$ (Cikadu) to $27.56 \%$ (Cilembu) while disease severity ranged from $7.92 \%$ (Cikadu) to $57.00 \%$ (Cilembu). Based on potato dextrose agar (PDA) culture plates, $68.57 \%$ of tubers were infected with various fungi. Among them, $M$. infuscans $(32.14 \%)$ was the most prevalent and most widely distributed pathogen associated with the scurf disease across sweet potato fields in West Java, Indonesia. To effectively manage the disease and improve farmers' income, it is imperative to establish effective and sound integrated disease mitigation strategies based on the results of this survey.
\end{abstract}

Keywords: Bandung, Bogor, Chaetosphaeriales, Cianjur, fungal disease, Garut, Kuningan, severity, Sumedang, incidence

\section{INTRODUCTION}

Sweet potato (Ipomoea batatas (L.) Lam.) is one of the most widely adapted food crops in the world. It is widely grown by farmers in rural areas or cultivated as a commercial crop (Loebenstein and Thottappilly 2009; Nafi'ah et al. 2021). Besides issues of yield stability and non-uniformity of tuber size, sweet potato production is also facing postharvest challenges including, skinning injury. Skinning causes the tuber to become wrinkled, cracked, and dried, thereby losing its weight with increase in exposure to pathogen attack and an unsightly appearance (Klipcan et al. 2020; Krochmal-marczak et al. 2020; Maulana et al. 2020). Currently, sweet potato has become the main income of farmers in production areas in West Java, Indonesia (Maulana et al. 2016). Sweet potato farmers can engage in small, medium, or large scale production because this commodity has relatively low production cost, simple cultivation techniques, low risk of crop failure, longer storability, and open market system (Zuraida 2003). The quality of sweet potatoes at harvest time determines the income received by farmers. In the production areas of West Java, sweet potato is classified into three classes, $\mathrm{A}, \mathrm{B}$ and $\mathrm{C}$, with each class priced differently. Classes $\mathrm{A}$ and $\mathrm{B}$ are meant for exports and supermarkets in Indonesia, while class $\mathrm{C}$ is for traditional market or for cattle feed. Sweet potato is normally classified based on size, shape and damage by farming tools, as well as injury by pests and diseases (Maulana et al. 2016). Therefore, farmers need to be trained on pest and disease management so they can produce high quality crops that command a better price.

Plant diseases, including biological and non-biological factors, play an important role in limiting the production of high-end classes of sweet potato tubers (Clark et al. 2013). Numerous fungal pathogens cause sweet potato diseases at various growth stages in the field and during storage. Scurf disease caused by and Ascomycete fungus Monilochaetes infuscans Halsted ex Harter (Chaetosphaeriales, Australiascaceae). The disease caused by $M$. infuscans was treated as a sweet potato postharvest disease, even if the infection often occurs before harvest (Elkner 2014; Meyers 2013). Under humid storage conditions, this fungus is known to produce purple or grayish-brown to black spores on the tuber skin, which can be observed on the infected part by using a microscope or a hand lens (QuesadaOscampo 2015). One of the characteristics of this fungus is slow growth when compared with other fungal species, such as Alternaria or Cladosporium, which have similar colony morphology. Microscopy of this species reveals a 
small colony with a slightly dark gray surface. At the early stage, branched, septate, and hyaline mycelium occur which later turn to gray. While the older colony is blackish with oily appearance on the surface. The conidiophores of $M$. infuscans are distinct from the mycelium, the older growth of which is also dark. Conidia are borne in chains that readily crumble when moistened or disturbed (International Potato Center 1988; Taubenhaus 1915). Colonization is confined in the periderm, however, the pathogen spreads until spots occur on all root and underground stem surfaces depending on the soil type and organic matter composition (Lawrence et al. 1981; Ferrin et al. 2008). Scurf can survive over one to two years in the soil, spreading the disease through cuttings and infected plants used from the previous season (Elkner 2014).

The causal agent of scurf disease can spread in the field with improper use of manure. The accumulation of manure and typical soil structure can trigger $M$. infuscans infestation on sweet potato fields (Quesada-Oscampo 2015). Limited certified seed stock is also a problem. The practice of farmers using infected seeds, can escalate scurf infections in the field (Clark et al. 2013). Favorable environmental conditions, such as high humidity and high temperature can lead to fungal development resulting in rapid scurf growth on the tuber (Taubenhaus 1915). In general, crop rotation for disease management is achieved by planting non-host plants to break the cycle of pathogens in the soil or to bring down pathogen populations below the control threshold (McGrath, 2009). Sweet potatoes cannot be grown continuously, year after year, even on optimum land areas, without serious risk of building up various disease-causing organisms or pests, that can threaten both yield and quality (Steinbauer and Kushman 1971).

Sweet potato diseases pose serious problem wherever sweet potatoes are grown, even if control measures are available. Little is known about the distribution and prevalence of scurf disease in Indonesia even if it is considered as a serious threat in Italy, USA, Japan, Pacific Islands, and Australia (HAL Project 2014; Lenna et al. 1999). It is important to understand the distribution and actual prevalence of this disease to determine changes in disease distribution patterns in the future. This study was conducted to measure the distribution and prevalence of scurf in West Java as the foundation in establishing appropriate and sound disease management strategies.

\section{MATERIALS AND METHODS}

\section{Field survey and samples collection}

A disease survey of six major sweet potato production areas between Sampora, Kuningan District ( $6^{0} 50^{\prime} 50^{\prime \prime} \mathrm{S}$; $108^{0} 30^{\prime} 0$ " W) and Cikadu, Cianjur District ( $7^{0} 19^{\prime} 32.4$ " $\mathrm{S} ; 107^{0} 15^{\prime} 08.1$ "W) (Table 1), was conducted during the crop season 2016-2017. Fields within this area, owned by farmer cooperators, were randomly selected. Inceptisol and Latosol are the prevalent soil types within this geographical area. Two to three fields per sweet potato production area were surveyed, totaling 28 fields. The plant materials used in this study were randomly collected during harvest, including both healthy and symptomatic sweet potato plant samples, which consist of stems, leaves and tubers. There were a total of 15-20 randomly collected samples per field (Adams et al. 1985). There was no prior knowledge on sweet potato scurf distribution and prevalence in these areas.

Isolates collected from the disease survey were obtained from each individual plant sample, including stems, leaves and all its tubers. Each field was sampled following a modified methodology as described by the Directorate of Plant Protection, Republic of Indonesia (Irianto 2018).

\section{Disease prevalence and crop damage assessment}

Collected tubers during the survey were counted, separated and washed. Then, 15 tubers were randomly selected to assess disease incidence and severity. Scurf disease prevalence was measured by collecting 420 random sweet potato tuber samples (15 samples per field), one week before harvest from 28 distinct fields in West Java province during 2016-2017. Each sample consisted of a single plant and all its tubers. The number of infected tubers per sample was counted, and disease incidence was declared whenever at least one infected tuber per plant was identified (Adams et al. 1985).

Table 1. Field locations, number of fields per area, GPS coordinates, seed resources, and cropping patterns practiced across disease survey areas in West Java (2016-2017)

\begin{tabular}{|c|c|c|c|c|c|c|}
\hline \multirow{2}{*}{ District } & \multirow{2}{*}{ Sampled area } & \multirow{2}{*}{$\begin{array}{l}\text { Number } \\
\text { of fields }\end{array}$} & \multicolumn{2}{|c|}{ Approximate GPS locations } & \multirow{2}{*}{ Seed resources } & \multirow{2}{*}{$\begin{array}{c}\text { Cropping } \\
\text { patterns }\end{array}$} \\
\hline & & & Latitude (S) & Longitude (E) & & \\
\hline \multirow[t]{5}{*}{ Kuningan } & Bandorasawetan & 3 & $6^{0} 52^{\prime} 56^{\prime \prime}$ & $108^{0} 29^{\prime} 22^{\prime \prime}$ & Kuningan & 1 \\
\hline & Cilimus & 3 & $6^{0} 52^{\prime} 25^{\prime \prime}$ & $108^{0} 29^{\prime} 55^{\prime \prime}$ & Kuningan & 1 \\
\hline & Setianegara & 3 & $6^{0} 52^{\prime} 26^{\prime \prime}$ & $108^{0} 28^{\prime} 13^{\prime \prime}$ & Kuningan & 1 \\
\hline & Linggaindah & 3 & $6^{0} 52^{\prime} 15^{\prime \prime}$ & $108^{0} 28^{\prime} 49^{\prime \prime}$ & Kuningan & 1 \\
\hline & Sampora & 3 & $6^{0} 50^{\prime} 50^{\prime \prime}$ & $108^{0} 30^{\prime} 0^{\prime \prime}$ & Kuningan & 2 \\
\hline Sumedang & Cilembu & 3 & $6^{0} 54^{\prime} 50^{\prime \prime}$ & $107^{0} 50^{\prime} 47^{\prime \prime}$ & Cilembu. Rancakalong & 3 \\
\hline Cianjur & Cikadu & 2 & 7019'32.4" & $107^{0} 15^{\prime} 08.1^{\prime \prime}$ & Jatinangor & 3 \\
\hline Bandung & Arjasari & 3 & $7^{\circ} 03^{\prime} 35.3^{\prime \prime}$ & $107^{\circ} 38^{\prime} 46.5^{\prime \prime}$ & Jatinangor & 4 \\
\hline Bogor & Dramaga & 2 & $6^{0} 33^{\prime} 00.7^{\prime \prime}$ & $108^{0} 43^{\prime} 42.9^{\prime \prime}$ & Jatinangor & 3 \\
\hline \multirow[t]{2}{*}{ Garut } & Karangpawitan & 3 & $7^{\circ} 12^{\prime} 20.2^{\prime \prime}$ & $107^{\circ} 56^{\prime} 15.0^{\prime \prime}$ & Jatinangor & 2 \\
\hline & Total & 28 & & & & \\
\hline
\end{tabular}

Note: Cropping patterns: 1. Sweet Potato-Sweet Potato-Rice; 2. Rice-Rice-Sweet potato; 3. Sweet potato all season; 4. Corn-Sweet potato-Corn 
Disease severity was visually evaluated by measuring the percentage of infected tuber surface area. This was accomplished by covering each tuber with transparent plastic and by delineating the infected tuber skin from the entire tuber skin area using a marker pen. The scurfinfected area was measured using AutoCAD map 2019. The percentage of scurf-infected area was determined by calculating the proportion of the scurf portion from the entire tuber area. The percentage of severity of scurf (Table 3 ) was calculated using modified assessment method (Agu et al. 2015):

$$
\operatorname{Sr}(\%)=\mathrm{a} / \mathrm{A} \times 100 \%
$$

Where:

$\mathrm{Sr}:$ Severity,

A : Healthy sweet potato tuber area

A : Scurf infected area

Analysis of variance and comparison of means administered using the SPSS 19.0 software.

\section{Isolation and Identification of Pathogen}

Fifteen symptomatic sweet potato tubers were randomly selected for the assessment of diseases. These randomly selected samples were used to identify suspected pathogens involved in the scurf infection of tubers from each field. Tuber samples were cut into $1 \mathrm{~cm}$ cubes, washed in $10 \%$ Clorox (sodium hypochlorite) for 1 minute, rinsed three times for one minute using sterile distilled water, and dried on sterile tissue paper. Each sweet potato cube was placed on potato dextrose agar (PDA) culture media. Fungal colonies were purified, and then the shape, diameter, and color of the fungal colonies were observed under $400 \times$ magnification of a binocular microscope. Identification of disease symptoms on the tubers, color, and morphology of fungal colonies, and fungal identification were performed based on Illustrated Genera of Imperfect fungi (Barnett and Hunter 1998). The number and identity of fungal species were recorded for each field. These data were used to identify fungal pathogens of sweet potato tubers and to assess the most prevalent fungal species associated with the scurf disease in West Java, Indonesia.

\section{RESULTS AND DISCUSSION}

\section{Environmental conditions in sweet potato fields during the disease survey}

Table 2 shows the environmental conditions across the sweet potato growing areas during the disease survey conducted between Sampora (Kuningan district) and Cikadu (Ciajur district). The environmental conditions appeared to have a strong influence on the distribution and prevalence of pathogen species affecting sweet potato scurf. The survey also showed that $50 \%$ of the farmers included in this survey were using crop rotation in their fields (Table 1).

\section{Diseases distribution, prevalence and crop damage assessment}

Scurf disease was present in almost every sweet potato production area. The prevalence and severity of scurf disease were evaluated across 28 fields in six districts of West Java province from 2016 to 2017 survey period (Figure 1).

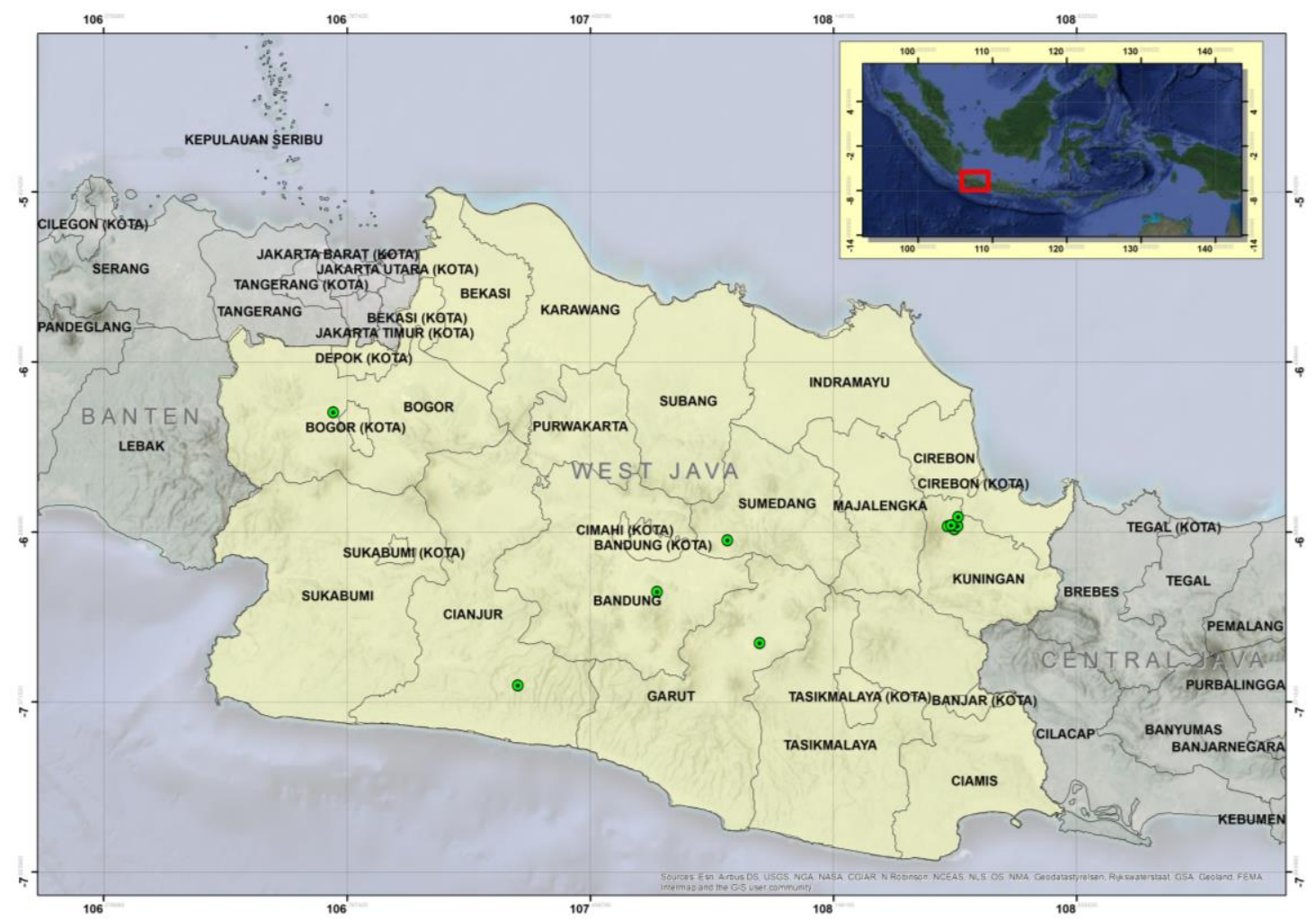

Figure 1. Distribution of scurf (M. infuscans) across six sweet potato areas in West Java, Indonesia 
Table 2. The environmental conditions of the study sites in six districts in West Java Province, Indonesia during the season 2016-2017

\begin{tabular}{|c|c|c|c|c|c|c|}
\hline Criteria & Bandung & Kuningan & Cianjur & Sumedang & Bogor & Garut \\
\hline \multicolumn{7}{|l|}{ Seed sources } \\
\hline Varieties & White AC & White AC, Rancing, Mawar & White AC, Rancing & Rancing & White AC, Rancing & White AC, Rancing \\
\hline Location & Bandung & Sumedang & Bandung & Sumedang & Bandung & Bandung \\
\hline \multicolumn{7}{|l|}{ Cultivation system } \\
\hline Cropping pattern & Rotation & Rotation & No rotation & No rotation & No rotation & Rotation \\
\hline Fertilizers used & Cow dung, Urea, & Cow dung Urea & Urea, Cow dung & Urea, $\mathrm{KCl}$, SP 36 , cow dung & Urea, cow dung & Urea, Cow dung \\
\hline Pesticides used & No pesticide & Carbofuran & No pesticide & Carbofuran & No pesticide & No pesticide \\
\hline \multicolumn{7}{|l|}{ Harvest } \\
\hline Growing method & Traditional & Traditional & Traditional & Traditional & Traditional & Traditional \\
\hline Growing period & 4-5 months & 4-5 months & 4-5 months & 4-5 months & 4-5 months & 4-5 months \\
\hline Storage & Storage & Storage & No storage & Storage & No storage & No storage \\
\hline Marketing & Direct selling & Direct selling, export & Direct selling & Direct selling, export & Direct selling & Direct selling \\
\hline \multicolumn{7}{|l|}{ Pest organisms } \\
\hline Insect/pest & $\begin{array}{l}\text { Rat (Rattus sp.), Sweet potato } \\
\text { weevil (Cylas formicarius) }\end{array}$ & $\begin{array}{l}\text { Rat, } C \text {. formicarius, gall } \\
\text { mites (Eriophyidae) }\end{array}$ & Rat, C. formicarius, & Rat, C. formicarius, & Rat, C. formicarius, & Rat, C. formicarius, \\
\hline Diseases & $\begin{array}{l}\text { Malformation of young leaves } \\
\text { (scab symptoms), leaf } \\
\text { discoloration, soft rot, scurf }\end{array}$ & $\begin{array}{l}\text { Leaf discoloration, brown } \\
\text { spot on stem base, soft rot, } \\
\text { dry rot, scurf }\end{array}$ & $\begin{array}{l}\text { Dry rot, scurf, } \\
\text { blackish-brown spots }\end{array}$ & $\begin{array}{l}\text { Yellow to dry leaves, soft } \\
\text { rot, black spots, scurf, } \\
\text { blackish-brown spots }\end{array}$ & $\begin{array}{l}\text { Yellow to dry leaves, soft } \\
\text { rot, black spots, scurf, } \\
\text { blackish-brown spots }\end{array}$ & $\begin{array}{l}\text { Soft rot, dry rot, black } \\
\text { spots, scurf, blackish- } \\
\text { brown spots }\end{array}$ \\
\hline
\end{tabular}


Table 3 shows that the number of tubers per plant between fields were significantly different and ranged from 3.20 to 4.80 with an average of 4.26 tubers per plant. Incidence of $M$. infuscans was observed across all sweet potato fields surveyed in this study and the differences observed were statistically significant. Furthermore, the number of infected plants between fields varied significantly. Based on all infection indices, the Cilembu fields had the highest incidence of scurf (27.56\%), which was statistically different from those in other fields. By contrast, infected plants per field at Cikadu and Karangpawitan locations were the lowest $(1.68 \%$ and $3.09 \%$ respectively). Scurf incidence in other areas ranged from $3.09 \%$ to $21.65 \%$.

Based on disease severity of $M$. infuscans, traditional plant varieties planted in the Cilembu and Setianegara fields were the most susceptible while those grown in Cikadu field were the most resistant. Disease severity in the Cilembu field was the highest among the surveyed areas, while the Cikadu, Darmaga, and Arjasari fields were the lowest. The percentage of tuber surface covered by scurf significantly varied from $7.92 \%$ up to $57 \%$ suggesting the severity of the disease infection.

\section{Isolation and identification of pathogens}

Macroscopic and microscopic observations of collected samples found seven fungal isolates associated with sweet potato tubers. Fungal isolates were identified based on their morphological features (Barnett and Hunter 1998). Analysis of culture plates indicated that $68.57 \%$ of tubers were infected with various fungi, while the rest showed no fungal growth. The main fungal genera associated with sweet potato tubers were Monilochaetes, Alternaria, Rhizopus, Aspergillus, Penicillium and Fusarium (Table 4). $M$. infuscans was found as the most prevalent fungal species present. The fungus was isolated from $32.14 \%$ of the samples, both from the stem base of the tuber and the tuber. A. solani and R. nigricans were identified on $10.71 \%$ and $5.71 \%$ of the samples, respectively. A. solani is known as a saprophytic fungus, but it can turn pathogenic, causing soft rot disease under a suitable host and favorable environment. $F$. solani and $F$. oxysporum were isolated from $7.14 \%$ and $3.57 \%$ of the tubers, respectively. The two fungal species are pathogenic and can infect tubers both in the field and in storage. The genera of Aspergillus and Penicillium were isolated from $4.29 \%$ and $5.71 \%$ of the tubers, respectively. Both fungi are facultative pathogens as they generally live through saprophytic mode but may turn pathogenic on suitable hosts and favorable environments.

Table 3. Incidence of scurf caused by M. infuscans at harvest time across 28 fields in West Java, 2016-2017.

\begin{tabular}{lcccc}
\hline \multicolumn{1}{c}{ Sampled area } & Tubers per plant & \multicolumn{3}{c}{ Infection indices } \\
\cline { 2 - 5 } & $4.33 \pm 0.176 \mathrm{ab}$ & $21.65 \pm 3.444 \mathrm{ab}$ & Infected tubers per sample & Severity \\
\hline Bandorasa Wetan & $4.73 \pm 0.176 \mathrm{ab}$ & $13.70 \pm 1.493 \mathrm{c}$ & $3.67 \mathrm{ab}$ & $40.20 \mathrm{ab}$ \\
Cilimus & $4.33 \pm 0.371 \mathrm{ab}$ & $11.73 \pm 2.125 \mathrm{c}$ & $4.00 \mathrm{ab}$ & $41.81 \mathrm{ab}$ \\
Setianegara & $4.80 \pm 0.116 \mathrm{a}$ & $10.72 \pm 0.160 \mathrm{c}$ & $4.00 \mathrm{ab}$ & $49.17 \mathrm{a}$ \\
Lingga Indah & $4.73 \pm 0.267 \mathrm{ab}$ & $7.84 \pm 1.940 \mathrm{~cd}$ & $4.00 \mathrm{ab}$ & $39.67 \mathrm{ab}$ \\
Sampora & $4.80 \pm 0.231 \mathrm{a}$ & $27.56 \pm 0.682 \mathrm{a}$ & $4.33 \mathrm{a}$ & $25.91 \mathrm{bc}$ \\
Cilembu & $3.90 \pm 0.300 \mathrm{abc}$ & $1.68 \pm 0.080 \mathrm{e}$ & $4.33 \mathrm{a}$ & $57.00 \mathrm{a}$ \\
Cikadu & $3.60 \pm 0.116 \mathrm{bc}$ & $19.28 \pm 5.470 \mathrm{~b}$ & $2.50 \mathrm{~b}$ & $7.92 \mathrm{~d}$ \\
Arjasari & $3.20 \pm 0.400 \mathrm{c}$ & $9.68 \pm 2.800 \mathrm{c}$ & $4.33 \mathrm{a}$ & $15.42 \mathrm{~cd}$ \\
Dramaga & $4.20 \pm 0.200 \mathrm{abc}$ & $3.09 \pm 0.888 \mathrm{de}$ & $2.50 \mathrm{~b}$ & $14.17 \mathrm{~cd}$ \\
Karangpawitan & Sa & $2.67 \mathrm{ab}$ & $25.56 \mathrm{bc}$ \\
\hline
\end{tabular}

Note: Incidence: at least one infected tuber per plant identified (percentage of infected plant). Prevalence: average infected tubers per sample (15 tubers per sample); Severity: measuring the scurf area, the percentage of scurf was determined by calculating the scurf portion from the entire area of a whole tuber. Means followed by the same letter(s) are not significantly different at $p<0.05$. Means followed by the not same letter(s) are significantly different at $\mathrm{p}<0.05$.

Table 4. Percentage of isolated pathogens and the most common genera of fungi isolated from sweet potato tubers collected across 28 fields in West Java, Indonesia.

\begin{tabular}{|c|c|c|c|c|c|c|c|c|c|c|}
\hline \multirow{2}{*}{ Sample area } & \multirow{2}{*}{ District } & \multirow{2}{*}{ Fields } & \multicolumn{8}{|c|}{ Percentage of Isolated pathogen (\%) } \\
\hline & & & Mi & Alte & Rhiz & Asp & Pen & Fus & Fuo & Not infected \\
\hline Bandorasa Wetan & Kuningan & 3 & 2.86 & 0.71 & 2.14 & - & 0.71 & 1.43 & 1.43 & 1.43 \\
\hline Cilimus & Kuningan & 3 & 3.57 & 0.71 & - & - & - & 0.71 & - & 5.71 \\
\hline Setianegara & Kuningan & 3 & 3.57 & 1.43 & - & 1.43 & 0.71 & 0.71 & - & 2.86 \\
\hline Lingga Indah & Kuningan & 3 & 4.29 & 0.71 & 0.71 & - & 1.43 & - & - & 3.57 \\
\hline Sampora & Kuningan & 3 & 3.57 & 1.43 & 0.71 & 1.43 & - & 1.43 & - & 2.14 \\
\hline Cilembu & Sumedang & 3 & 5.00 & 0.71 & - & 0.71 & - & 0.71 & - & 3.57 \\
\hline Cikadu & Cianjur & 2 & 2.14 & 1.43 & - & - & - & - & - & 3.57 \\
\hline Arjasari & Bandung & 3 & 2.86 & 1.43 & 0.71 & 0.71 & - & - & 2.14 & 2.86 \\
\hline Dramaga & Bogor & 2 & 2.14 & 0.71 & 0.71 & - & 1.43 & 0.71 & - & 1.43 \\
\hline Karang Pawitan & Garut & 3 & 2.14 & 0.71 & 0.71 & - & 1.43 & 1.43 & - & 4.29 \\
\hline Total & & 28 & 32.14 & 10.71 & 5.71 & 4.29 & 5.71 & 7.14 & 3.57 & 31.43 \\
\hline
\end{tabular}




\section{Discussion}

Traditionally, in non-irrigated areas of West Java, Indonesia, sweet potatoes are often planted in rotation with corn and rice. This crop rotation scheme has long been practiced by local gfarmers to generate more income on their farms per season. Multi-cropping or planting different types of crops every season has also been practiced by Chinese farmers since ancient times to make farming more profitable (Francis 2005). The crop rotation system in Kuningan district is regulated based on the availability of irrigation and includes sweet potato-corn-rice crop rotation pattern. By contrast, most of the surveyed areas in Sumedang and Bogor districts planted sweet potatoes throughout the year. The influence of non-host crops in reducing disease pressure was demonstrated in Cianjur, a new planting area. Cianjur had been previously planted with corn and had low disease pressure. This emphasizes the role of cropping patterns in influencing disease development. Using infected seeds could also lead to severe disease incidence and severity. This is further exacerbated by the common practice of farmers of leaving crop residues in the fields, allowing continuity of the disease life cycles of many destructive pathogens. One of the advantages using cropping systems, like crop rotation, is the interruption of the disease life cycle (Francis 2005). Crop rotation can be useful for controlling pathogens that persist in the soil for several years (Schneekloth et al. 1991). However, for crop rotation to be effective, it is important to use crops from different families. This was demonstrated in Cianjur, which showed low disease incidence after alternating with plantation of corn. However, it is important to remember that there are also broad-spectrum pathogens that can infect plants of more than one family (McGrath 2009). The disease survey conducted to assess the incidence and severity of scurf ( $M$. infuscans) on sweet potatoes in West Java province revealed that the pathogen was found across all sampled fields with various degrees of severity. Results indicated that scurf could be considered as one of the major diseases of sweet potatoes in West Java province. This problem has gone unnoticed because the disease is not directly associated with yield losses, and symptoms cannot be easily seen from above the ground. One of the many possible reasons for the scurf prevalence in West Java production areas is the quality of seeds used by farmers. Most sweet potato growers use seeds from local sources. They use vine cuttings taken from previous growing seasons from either their fields or neighboring ones. The fungus most likely has already contaminated the seeds derived from infected plants. The use of infected planting materials is perhaps the leading cause of scurf disease development (Nærstad et al. 2012).

The prevalence of scurf in fields continuously planted with sweet potatoes is very high. The disease survey showed that in areas where farmers applied crop rotation, the incidence of scurf disease was less prevalent. These sweet potato growers practiced different cropping patterns in various production areas. In West Java, 30\% of sweet potato growers have cultivated the plant throughout the year, $40 \%$ of them used to plant sweet potatoes twice a year during the rainy season, while others (10\%) apply intercropping practices between sweet potatoes and maize (Table 2). In the subdistrict of the Cilembu Sumedang, sweet potato is the main source of farmers' income. Here, the prevalence and severity of $M$. infuscans is very high because sweet potato cultivation continues throughout the year. Most farmers practice monoculture system using a single cultivar, Rancing, which contributed significantly to the prevalence and severity of the disease. Pathogenic infections are more prevalent and severe in large areas that only use single cultivars, such as commercial farms, compared to small farms (Thompson et al. 2011). In addition, traditional farmers, including sweet potato growers, are usually less concerned with field sanitation. The use of uncertified sweet potato tubers and contaminated tools seems to contribute to the prevalence and widespread severity of the disease. Healthy roots may be contaminated with fungal spores from diseased sources and contaminated crates, baskets and storage houses. During grading operations, spores from infected roots are dislodged with soil and disseminated by air currents, contaminated containers and infected tubers. Many factors affect the incidence and severity of sweet potato scurf including seed quality, cultivars, crop rotation, fertilization, irrigation, soil management, insect and pest management, field sanitation, crop residue management, weed management and disease management (Meyers 2013).

In the 2017 disease survey, comparisons were made between sweet potato yield from heavily infected fields with those from less severely attacked areas. No significant correlations between disease prevalence and severity with potato yields were detected, suggesting that scurf did not have an impact on yield reduction. No significant sweet potato yield reduction caused by $M$. infuscans was also previously reported (Lenna et al. 1999; Meyers 2013). Scurf is known as a fungal disease that is only skin deep and does not affect the palatability of sweet potatoes. However, sweet potatoes with scurf have unsightly purple, brown, and gray to black lesions, which cause consumers to shy away from these sick-looking sweet potatoes (Figure 2).

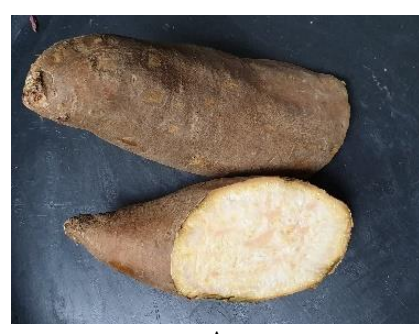

A

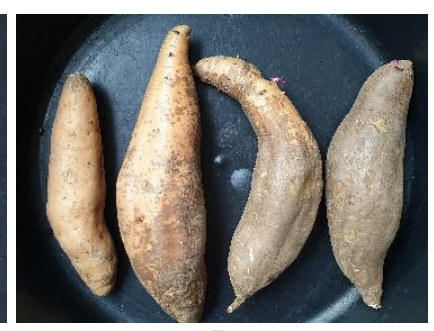

B
Figure 2. Scurf sick looking appearance on white flash sweet potato on sweet potato center district in West Java: (A) Scurf skin discoloration; (B) Range of scurf disease severity. 
Scurf might not significantly affect yield but can have a significant negative impact on farmers' income. Most sweet potato production in West Java was used for local and export markets. Normally, there are three sweet potato classes, A, B, C sold at local markets, which also accept scurf-infested sweet potatoes, especially when production is low. Local culture believes that sweet potato tuber with more stains on its skin is sweeter and tastes like honey. Farmers are not aware that this stain is a fungus that damages sweet potatoes in storage and reduces consumer preference and acceptance. Traders buy class A sweet potato at a price of IDR 3500-IDR 5000 per kilogram. Currently, only a small portion sweet potato tubers are classified as class A, most are classes B and C, which command lower prices. By contrast, sweet potatoes without scurf stains can be exported at IDR 7000-IDR 10000 per kilogram. To increase the proportion of class 'A' tubers improve farmers' income, appropriate disease management strategies need to be established.

Further study should be conducted to measure the rate of disease development after harvest and to identify factors that support disease development under storage conditions. Farmers should apply an integrated approach to manage sweet potato scurf (Clark et al. 2013; Meyers 2013). This integrated approach includes planting clean and healthy seeds in a disease-free environment, field sanitation, and crop rotation. The use of molecular markers in conjunction with traditional breeding methods of developing scurfresistant and high-yielding varieties is strongly recommended.

In conclusion, overall, this research is the first scurf disease survey in Indonesia. Scurf was distributed in almost all sweet potato production areas in West Java. The incidence of scurf ranged from $1.68 \%$ (Cikadu) to $27.56 \%$ (Cilembu). The severity of scurf significantly varied from $7.92 \%$ (Cikadu) to $57 \%$ (Cilembu). The main fungal genera associated with sweet potato tuber disease in West Java were Monilochaetes, Alternaria, Rhizopus, Aspergillus, Penicillium, Fusarium and $M$. infuscans. The most prevalent species was $M$. Infuscans, isolated from $32.14 \%$ of the tubers sampled. To mitigate the effect of the scurf disease and improve farmers' income, an integrated approach to manage sweet potato scurf has to be taught to farmers and implemented across major sweet potato growing areas. The use of clean and healthy seeds in a disease-free environment, field sanitation, and crop rotation should be emphasized. To develop scuff-resistant and highyielding varieties, the use of molecular markers in conjunction with traditional breeding methods is strongly recommended.

\section{ACKNOWLEDGEMENTS}

We all thank the Governor of West Java Province, Office of Food Crops and Horticulture of West Java Province for supporting this study; Center of Pest and Disease Forecasting Jatisari, MoA for guiding the identification of isolates; I. Suhardiman for his guidance during the survey; and the numerous sweet potato farmers in West Java that allowed us to sample diseased storage roots. This study was funded by The Governor of West Java Province, through Independent Research Application Fee Assistance, number: 890/ Kep-946/ Bangrir-BKD/2016 and Funding Assistance for Doctoral Education Research, number: 071/ Kep-651-BKD/2018. This study was partially funded by Sensient Colors, LLC, USA. The authors declare no conflict of interest.

\section{REFERENCES}

Adams MJ, Hide GA, Lapwood DH. 1985. Sampling potatoes for the incidence of tuber diseases and levels of inoculum. Ann Appl Biol 107 (2): 189-203. DOI: 10.1111/j.1744-7348.1985.tb01562.x.

Agu KC, Nweke GU, Awah NS, Okeke BC, Mgbemena ICC, Okigbo RN, Ngenegbo UC. 2015. Fungi Associated with the Post-Harvest Loss of Sweet Potato. Intl J Res Studies in Biosci 3 (9): 33-38.

Barnett HL, Hunter BB. 1998. Illustrated Genera of Imperfect Fungi Fourth edition. The American Phytopathological Society, Minnesota.

Clark CA, Ferrin DM, Smith TP, Holmes GJ. 2013. Compendium of Sweetpotato Diseases, Pest and Disorders. The American Phytopathological Society, Minnesota.

Elkner T. 2014. Scurf on Sweet Potato. PennState Extention. https://extension.psu.edu/scurf-on-sweet-potato.

Ferrin D, Smith T, Clark C. 2008. Scurf of Sweet Potato. Lousiana Plant Pathology: Disease Identification and Management Series. LSU AgCenter, Baton Rouge, LA, USA.

Francis CA. 2005. Crop Rotations. In: Hillel D (ed.) Encyclopedia of Soils in the Environment. Elsevier, Nederland. DOI: 10.1016/B0-12348530-4/00253-8.

HAL Project. 2014. Sweet Potatoes Strategic Agrichemical Review Process 2011-2014. Horticulture Australia (HAL), Australia. AgAware Consulting Pty Ltd \& Checkbox 3D Pty Ltd, Beecroft, NSW.

International Potato Center. 1988. Exploration, maintenance, and utilization of sweet potato genetic resources: report of the first sweet potato planning conference 1987. International Potato Center (CIP), Lima, Peru.

Irianto SG. 2018. Petunjuk Teknis Pengamatan dan Pelaporan Organisme Pengganggu Tumbuhan dan Dampak Perubahan Iklim (OPT-DPI) (Revised Ed). Ministry of Agriculture of the Republic of Indonesia, Jakarta. [Indonesian]

Klipcan L, van Oss R, Keren-Kieserman A, Yermiyahu U, Ginzberg I. 2020. Potassium positively affects skin characteristics of sweet potato storage roots. Agronomy 10: $1385 . \quad$ DOI: 10.3390/agronomy10091385.

Krochmal-Marczak B, Sawicka B, Krzysztofik B, Danilčenko H, Hariene E. 2020. The Effects of Temperature on the quality and storage stalibity of Sweet Potato (Ipomoea batatas L. [Lam]) Grown in Central Europe. Agronomy 10: 1665. DOI 10.3390/agronomy10111665.

Lawrence GW, Moyer JW, van Dyke CG. 1981. Histopathology of Sweet Potato Roots Infected with Monilochaetes infuscans. Phytopathology 71: 312-315. DOI: 10.1094/Phyto-71-312.

Lenna PD, Mascarello N, Xodo E. 1999. First report of sweet potato scurf caused by Monilochaetes infuscans in Italy. Plant Disease 83 (3): 300. DOI: 10.1094/PDIS.1999.83.3.300B.

Loebenstein G, Thottappilly G. 2009. The sweet potato. Springer Netherlands. DOI: 10.1007/978-1-4020-9475-0.

Maulana H, Dewayani S, Solihin MA, Arifin M, Amien S, Karuniawan A. 2020. Yield stability dataset of new orange-fleshed sweet potato (Ipomoea batatas L. (lam)) genotypes in West Java, Indonesia. Data in Brief 32: 106297. DOI: 10.1016/j.dib.2020.106297.

Maulana H, Nugroho DM, Trimo L, Karuniawan A. 2016. Participatory selection of sweet potato based on farmers preferences in Banjar city. Proceedings of SABRAO 13th Congress and International Congress. IPB University, Bogor, 14-16 September 2015. [Indonesian]

McGrath MT. 2009. Managing Plant Diseases With Crop Rotation. In: Mohler CL, Johnson SE (eds) Crop rotation on organic farms: A planning manual. SARE, Brentwood MD. 
Meyers S. 2013. Sweetpotatoes and Scurf. Mississipi crop situation Mississippi State University Extention, MS, USA

Nærstad R, Dees MW, Le VH, Holgado R, Hermansen A. 2012. Occurrence of skin blemish diseases (scab and scurf) in Norwegian potato production. Potato Research 55(3-4): 225-239. DOI: 10.1007/s11540-012-9221-x.

Nafi'ah HH, Hindersah R, Mubarok S, Maulana H, Suganda T, Concibido V, Karuniawan A. 2021. Growth rate and yield response of several sweet potato clones to reduced inorganic fertilizer and biofertilizer. Biodiversitas 22(4): 1775-1782. DOI: 10.13057/biodiv/d220422.

Quesada-Oscampo L. 2015. Preventing sweet potato black rot and scurf. Extension Plant pathology. NC State Extension, NC State University, Raleigh, NC, USA.

Schneekloth JP, Klocke NL, Hergert GW, Martin DL, Clark RT. 1991. Crop rotations with full and limited irrigation and dryland management. Trans Am Soc Agric Eng 34 (6): 2372-2380. DOI: $10.13031 / 2013.31882$.

Steinbauer CE, Kushman LJ. 1971. Sweetpotato Culture and Diseases (388th ed.). Agricultural Research Service: United States Department of Agriculture, Washington DC.

Taubenhaus JJ. 1915. Soilstain, or scurf, of the sweet potato. J Agric Res 5 (21): 995-1002.

Thompson AH, Narayanin CD, Smith MF, Slabbert MM. 2011. A disease survey of Fusarium wilt and Alternaria blight on sweet potato in South Africa. Crop Protect 30 (11): 1409-1413. DOI: 10.1016/j.cropro.2011.07.017.

Zuraida N. 2003. Sweet potato as an alternative food supplement during rice shortage. Jurnal Litbang Pertanian 22 (4): 150-155. 